\title{
Parkinson’s Disease Associated with Myasthenia Gravis: A Case Report and Literature Review
}

Rahma Beyrouti ${ }^{*}$ Sylvie Courtois, Andreas Fickl and Elie Cohen

Department of Neurology, Emile Muller Hospital, Mulhouse, France

*Corresponding author: Rahma Beyrouti, Department of Neurology, Emile Muller Hospital, Mulhouse, France, Tel: +33698534085; E-mail: rahma.beyrouti@gmail.com Rec date: Jul 02, 2016; Acc date: Jul 26, 2016; Pub date: Jul 28, 2016

Copyright: ( 2016 Beyrouti R, et al. This is an open-access article distributed under the terms of the Creative Commons Attribution License, which permits unrestricted use, distribution, and reproduction in any medium, provided the original author and source are credited.

Keywords: Parkinson's disease; Movement disorders; Myasthenia gravis; Neuromuscular disorders

\section{Introduction}

The prevalence of Parkinson's disease (PD) in the elderly population exceeds $1 \%$ according to recent reports, whereas myasthenia gravis (MG) is much rarer [1]. The expected prevalence of the combination of MG and PD can be grossly estimated to 3 cases per 6 million [2]. To our knowledge, since 1987, 12 cases of concurrent PD and MG have been reported [3]. We report a new case of PD associated with MG with update literature review.

\section{Case Report}

A 73-year old man with a 20-year history of akineto-hypertonic form of Parkinson's disease, presented with fluctuating ptosis, diplopia, slurring of speech, dysphagia and general weakness of the neck, trunk and four limbs. These symptoms worsened during the course of the day but were better in the morning and after rest. On admission the patient was alert and orientated. General physical examination was unremarkable. On neurological examination, the strength of the neck extensors was reduced to $2 / 5$ according to the Medical Research Council's score; the strength of both sternocleidomastoids was $3 / 5$. All the remaining muscles were scored 5/5. Severe camptocormia, bradykinesia and rigidity were also noted. Routine blood and urine exams were unremarkable. Injection of Neostigmine dramatically improved his ptosis, slurred speech, dysphagia and muscle weakness. A typical decremental response was shown in deltoid and bilateral facial muscles on $3 \mathrm{~Hz}$ supramaximal stimulation. Serum acetylcholine receptor antibody $(\mathrm{AChR} \mathrm{Ab}$ ) titers were $17.3 \mathrm{nmol} / \mathrm{l}$ (normal $<0.2$ $\mathrm{nmol} / \mathrm{l}$ ) when antibodies to muscle-specific tyrosine kinase (MuSK) and antibodies against presynaptic voltage-gated calcium channels were negative. CT scan of the mediastinum revealed the presence of a thymus gland enlargement of $34 \times 22 \times 26 \mathrm{~mm}$. On the basis of the above-mentioned clinical, immunological screening and neurophysiological findings a diagnosis of MG was established. The patient was treated only with pyridostigmine $(120 \mathrm{mg} /$ day $)$. Remarkable improvement following treatment was reported.

\section{Discussion}

Ueno was the first to describe a patient where PD and MG coexisted [4]. However, since then a possible link between PD and MG has been suggested in 11 more published cases [1-8]; their demographic and clinical characteristics are summarized in Table 1. Our patient is the thirteenth to be reported where these two medical entities coexist.

\begin{tabular}{|c|c|c|c|c|c|c|c|}
\hline Year & Author & Case/series & First diagnosis & $\begin{array}{l}\text { Age at second } \\
\text { diagnosis }\end{array}$ & Sex & Antibodies detected & MG presenting symptom \\
\hline 1987 & Ueno et al. & Single case & PD & 60 & M & $\operatorname{AChR}(+)$ & $\begin{array}{l}\text { Dropped head, ptosis, } \\
\text { diplopia }\end{array}$ \\
\hline 1993 & Kao et al. & Single case & PD & 62 & $\mathrm{~F}$ & $\mathrm{AChR}(+)$ & $\begin{array}{l}\text { Unilateral ptosis, diplopia, } \\
\text { slurred speech and } \\
\text { generalized weakness }\end{array}$ \\
\hline \multirow[t]{4}{*}{2003} & Levin et al. & Case \#1 & PD & 76 & M & $\mathrm{AChR}(+)$ & Dropped head \\
\hline & & Case \#2 & PD & 62 & M & $\operatorname{AChR}(+)$ & $\begin{array}{l}\text { Unilateral ptosis, lower limb } \\
\text { weakness, } \\
\text { dysphagia and dyspnea }\end{array}$ \\
\hline & & Case \#3 & MG & 68 & $\mathrm{~F}$ & $\operatorname{AChR}(+)$ & Limb weakness and ptosis \\
\hline & & Case \#4 & PD & 61 & M & No available & Bilateral ptosis \\
\hline 2008 & Fasano et al. & Single case & PD & 58 & $\mathrm{~F}$ & AChR(-) Anti-MuSK(-) & Dropped head \\
\hline 2009 & $\begin{array}{l}\text { Unal-cevik and } \\
\text { Temucin }\end{array}$ & Single case & PD & 84 & M & AChR(-) & Dropped head \\
\hline 2011 & Uldag et al. & Single case & PD & 75 & M & $\operatorname{AChR}(+)$ & Dropped head \\
\hline
\end{tabular}


Page 2 of 2

\begin{tabular}{|c|c|c|c|c|c|c|c|}
\hline 2013 & Zis et al. & Single case & PD & 69 & M & $\begin{array}{l}\operatorname{AChR(+)} \quad \text { Anti- } \\
\operatorname{MuSK}(-)\end{array}$ & Dropped head \\
\hline \multirow[t]{2}{*}{2014} & Leslie et al. & Case \#1 & PD & 75 & $\mathrm{~F}$ & $\operatorname{AChR}(+)$ & $\begin{array}{l}\text { Weakness of the limbs and } \\
\text { neck flexor muscles }\end{array}$ \\
\hline & & Case \#2 & PD & 72 & M & $\mathrm{AChR}(+)$ & $\begin{array}{l}\text { Bilateral ptosis and } \\
\text { ophtalmoplegia }\end{array}$ \\
\hline \multirow[b]{2}{*}{2016} & \multirow{2}{*}{ Beyrouti et al. } & \multirow{2}{*}{ Single case } & \multirow[b]{2}{*}{ PD } & \multirow[b]{2}{*}{73} & \multirow{2}{*}{ M } & $\operatorname{AChR}(+)$ & \multirow{2}{*}{$\begin{array}{l}\text { ptosis, diplopia, slurring of } \\
\text { speech, dysphagia and } \\
\text { general weakness of the } \\
\text { neck, trunk and four limbs }\end{array}$} \\
\hline & & & & & & Anti-MuSK(-) & \\
\hline
\end{tabular}

Table 1: Demographic and clinical characteristics of published data of patients suffering from PD and MG.

A male predominance, of approximately 2:1, has been observed [5]. The majority of the patients had a diagnosis of $\mathrm{PD}$, and MG was diagnosed few years later. Only in one patient MG preceded PD [1]. Nine patients were positive for AChR antibodies, two were negative, and for one there is no information available.

PD and MG share some similar clinical symptoms that may overlap each other. The main clinical feature of MG is abnormal fatigue, caused by autoimmune mediated disturbance of neuromuscular junction. In PD fatigue represents a very common sign as well. The pathogenesis and etiology of fatigue remain still unknown. In spite of rare coexistence of PD and MG, it is inevitable to pay regard to their overlapping signs. Dropped head is a frequent initial sign in MG and can mimic anterocollis in PD. Head drop in PD results from cervical dystonia or camptocormia, whereas in $\mathrm{MG}$ it is induced by neck muscle weakness [6]. Additional symptoms that may occur both in PD and MG include dysphagia, dysarthria, "weakness" of facial muscles, which can imitate hypomimia in $\mathrm{PD}$, myastenic ptosis resembling blepharospasm or motor fluctuation.

\section{Conclusion}

One must be vigilant to not overlook another potentially treatable neuromuscular condition contributing to clinical deterioration in patients with PD. Motor power is not affected in PD and muscle weakness obligates a search for another neurologic explanation.

\section{References}

1. Levin N, Karussis D, Abramsky O (2003) Parkinson's disease associated with myasthenia gravis. A report of 4 cases. J Neurol 250: 766-767.

2. Kao KP, Kwan SY, Lin KP (1993) Coexistence of Parkinson's disease and myasthenia gravis: A case report. Clin Neurol Neurosurg 95: 137-139.

3. Neuman LA, Cheema FZ (2014) Two cases of Parkinson disease and concurrent myasthenia gravis, generalized and ocular. The Neurohospitalist 4: 117-118.

4. Ueno S, Takahashi M, Kajiyama K, Okahisa N, Hazama T, et al. (1987) Parkinson's disease and myasthenia gravis: adverse effect of trihexyphenidyl on neuromuscular transmission. Neurology 37: 832-833.

5. Wang J, Wu X, Wu W, Zhang H, Liu K (2014) Parkinson 's disease associated with myasthenia gravis and rheumatoid arthritis. Neurol Sci 35: 797-799.

6. Fasano A, Evoli A, Piano C, Tonali PA, Bentivoglio AR (2008) Myasthenia gravis: an unrecognized cause of head drop in Parkinson's disease. Parkinsonism Relat Disord 14: 164-165.

7. Unal-Cevik I, Temucin CM (2009) Head drop in an elder Parkinson's disease after development of myasthenia gravis. Mov Disord 24: 2025-2026.

8. Uludag IF, Korucuk M, Sener U (2011) Myasthenia gravis as a cause of head drop in Parkinson disease. Neurologist 17: 144-146. 